\title{
Introduction to the special section on the 2007 Chuetsu-Oki, Niigata, Japan, Earthquake
}

\author{
Hiroshi Sato \\ Earthquake Research Institute, the University of Tokyo, 1-1-1 Yayoi, Bunkyo, Tokyo 113-0032, Japan \\ (Received October 13, 2008; Revised October 19, 2008; Accepted October 19, 2008; Online published November 18, 2008)
}

An $M_{\mathrm{JMA}} 6.8$ earthquake occurred in the offshore region of mid-Niigata prefecture, central Japan, on July 16, 2007. This earthquake killed 15 people, injured 2,016 others, and destroyed 1,300 dwellings in coastal regions along the Sea of Japan, especially in the city of Kashiwazaki. The Kashiwazaki-Kariya nuclear power plant, which is the largest nuclear generating station in the world, is located in the epicentral area and automatically powered down safely in response to the earthquake. The extended shutdown needed for its post-earthquake inspection and subsequent upgrades, however, had a significant impact on the Japanese economy. This earthquake also focused attention on some of the problems involved in providing a high level of anti-earthquake resistance to nuclear power plants in the Japanese islands.

This earthquake occurred in a fold-and-thrust belt along the coast of the Sea of Japan in northern Honshu, which has been marked as a failed rift formed in the Miocene associated with the opening of the Sea of Japan (e.g., Sato, 1994). The more than 6-km-thick Neogene basin fill shows active folding and thrusting, forming a zone of late Quaternary contraction. The coast of the Sea of Japan in Niigata prefecture is also located in the zone showing a high strain rate, as observed by the continuous GPS network (Sagiya, 2004), and has been hit by many destructive earthquakes in the past, such as the 1964 Niigata earthquake $\left(M_{\mathrm{JMA}} 7.4\right)$ and the 2004 mid-Niigata Prefecture earthquake $\left(M_{\mathrm{JMA}} 6.8\right.$; Hirata, 2005). Studies of the 2007 Chuetsu-Oki Earthquake, as well as the 2004 mid-Niigata Prefecture earthquake, will provide important information towards a better understanding of the generation of earthquakes and crustal deformations in the inverted back-arc rift basin.

The special section in this issue of Earth, Planets and Space is a collection of papers on the 2007 Chuetsu-Oki Earthquake. Immediately after the earthquake, onshore and offshore seismic observations were made with densely distributed seismometers. The observations of aftershocks together with the data acquired by the permanent seismic networks enabled the source fault geometry and velocity structure to be delineated (Kato et al., 2008; Mori, 2008; Nakajima and Hasegawa, 2008; Shinohara et al., 2008;

Copyright (c) The Society of Geomagnetism and Earth, Planetary and Space Sciences (SGEPSS); The Seismological Society of Japan; The Volcanological Society of Japan; The Geodetic Society of Japan; The Japanese Society for Planetary Sciences; TERRAPUB.
Yoshida, 2008; Yukutake et al., 2008). Interferometric synthetic aperture radar data and the GPS network (GEONET) provided essential information on the surface deformation. Based on the data provided by temporally installed instruments and field surveys, it has been possible to determine the co- and post-seismic deformation (Iinuma et al., 2008; Ohta et al., 2008) and to construct fault models (Nishimura et al., 2008; Ozawa, 2008; Aoki et al., 2008). The source process of the mainshock was inferred from strong motionseismograms (Aoi et al., 2008). Other aspects of the earthquake have also been characterized: the earthquake sequence (Tajima and Tajima, 2008) and a paleosismic investigation of emerged wood blocks (Kaneda et al., 2008).

We hope that these studies will contribute to an improved understanding of the 2007 Chuetsu-Oki Earthquake and provide fundamental knowledge for the mitigation of future seismic disasters produced by destructive earthquakes beneath thick sediment cover in a fold-and-thrust belt.

\section{References}

Aoi, S., H. Sekiguchi, N. Morikawa, and T. Kunugi, Source process of the 2007 Niigata-ken Chuetsu-oki earthquake derived from near-fault strong motion data, Earth Planets Space, 60, this issue, 1131-1135, 2008.

Aoki, Y., M. Furuya, and T. Kato, Coseismic deformation due to the 2007 Chuetsu-oki earthquake $\left(M_{\mathrm{w}}=6.8\right)$, Earth Planets Space, 60, this issue, 1075-1080, 2008.

Hirata, N., Introduction to the special section for the 2004 Mid-Niigata Prefecture Earthquake, Earth Planets Space, 57, i, 2005.

Iinuma, T., Y. Ohta, S. Miura, K. Tachibana, T. Matsushima, H. Takahashi, T. Sagiya, T. Ito, S. Miyazaki, R. Doke, A. Takeuchi, K. Miyao, A. Hirao, T. Maeda, T. Yamaguchi, M. Takada, M. Iwakuni, T. Ochi, I. Meilano, and A. Hasegawa, Postseismic slip associated with the 2007 Chuetsu-oki, Niigata, Japan, Earthquake ( $M 6.8$ on 16 July 2007) as inferred from GPS data, Earth Planets Space, 60, this issue, 1087-1091, 2008.

Kaneda, H., M. Nakata, Y. Hosoo, Y. Sugiyama, and Y. Okamura, Holocene ages and inland source of wood blocks that emerged onto the seafloor during the 2007 Chuetsu-oki, central Japan, earthquake, Earth Planets Space, 60, this issue, 1149-1152, 2008.

Kato, A., S. Sakai, E. Kurashimo, T. Igarashi, T. Iidaka, N. Hirata, T. Iwasaki, T. Kanazawa, and Group for the aftershock observations of the 2007 Niigataken Chuetsu-oki Earthquake, Imaging heterogeneous velocity structures and complex aftershock distributions in the source region of the 2007 Niigataken Chuetsu-oki Earthquake by a dense seismic observation, Earth Planets Space, 60, this issue, 1111-1116, 2008.

Mori, J., Determination of dip direction for the 2007 Chuetsu-oki earthquake from relocation of aftershocks using arrival times determined by cross-correlation, Earth Planets Space, 60, this issue, 1117-1120, 2008.

Nakajima, J. and A. Hasegawa, Existence of low-velocity zones under the source areas of the 2004 Chuetsu and 2007 Chuetsu-oki earthquakes inferred from travel-time tomography, Earth Planets Space, 60, this 
issue, 1127-1130, 2008

Nishimura, T., M. Tobita, H. Yarai, S. Ozawa, M. Murakami, T. Yutsudo, M. Ishimoto, T. Umesawa, T. Toyofuku, S. Kawamoto, T. Amagai, M. Fujiwara, A. Suzuki, S. Enya, T. Sasaki, M. Yokokawa, S. Oomori, S. Tanoue, H. Ikeda, M. Nemoto, H. Suito, F. Hayashi, H. Une, M. Koarai, and M. Tsuzawa, Crustal deformation and a preliminary fault model of the 2007 Chuetsu-oki earthquake observed by GPS, InSAR, and leveling, Earth Planets Space, 60, this issue, 1093-1098, 2008.

Ohta, Y., S. Miura, T. Iinuma, K. Tachibana, T. Matsushima, H. Takahashi, T. Sagiya, T. Ito, S. Miyazaki, R. Doke, A. Takeuchi, K. Miyao, A. Hirao, T. Maeda, T. Yamaguchi, M. Takada, M. Iwakuni, T. Ochi, I. Meilano, and A. Hasegawa, Coseismic and postseismic deformation related to the 2007 Chuetsu-oki, Niigata Earthquake, Earth Planets Space, 60, this issue, 1081-1086, 2008.

Ozawa, T., Coseismic deformatoin of the 2007 Chuetsu-oki earthquake derived from PALSAR/InSAR and its fault model, Earth Planets Space, 60, this issue, 1099-1104, 2008.

Sagiya, T., A decade of GEONET: 1994-2003-The continuous GPS observation in Japan and its impact on earthquake studies, Earth Planets Space, 56, 29-41, 2004.

Sato, H., 1994. The relationship between late Cenozoic tectonic events and stress field and basin development in northeast Japan, J. Geophys. Res., 99, 22261-22274, 1994
Shinohara, M., T. Kanazawa, T. Yamada, K. Nakahigashi, S. Sakai, R. Hino, Y. Murai, A. Yamazaki, K. Obana, Y. Ito, K. Iwakiri, R. Miura, Y. Machida, K. Mochizuki, K. Uehira, M. Tahara, A. Kuwano, S. Amamiya, S. Kodaira, T. Takanami, Y. Kaneda, and T. Iwasaki, Precise aftershock distribution of the 2007 Chuetsu-oki Earthquake obtained by using an ocean bottom seismometer network, Earth Planets Space, 60, this issue, 1121-1126, 2008 .

Tajima, R. and F. Tajima, Seismic scaling relation of the 2007 Off Mid Niigata, Japan, earthquake $\left(M_{\mathrm{W}} 6.6\right)$ sequence in comparison with two other earthquake $\left(M_{\mathrm{W}} 6.6\right)$ sequences, Earth Planets Space, 60, this issue, 1137-1141, 2008.

Yoshida, K., Seismic vertical array analysis of the velocity structure and phase decomposition during aftershocks of the 2007 Chuetsu-oki earthquake, Earth Planets Space, 60, this issue, 1143-1147, 2008.

Yukutake, Y., T. Takeda, and K. Obara, Well-resolved hypocenter distribution using the double-difference relocation method in the region of the 2007 Chuetsu-oki Earthquake, Earth Planets Space, 60, this issue, 1105-1109, 2008.

H. Sato (e-mail: satow@eri.u-tokyo.ac.jp) 